\title{
Long-Term Observations of Interannual and Decadal Variation of Sea Surface Temperature in the Taiwan Strait
}

\author{
Ming-An Lee \\ Center of Excellence for Ocean Engineering, National Taiwan Ocean University, Keelung, Taiwan, R.O.C. \\ Wei-Po Huang \\ EBFS, National Taiwan Ocean University, Keelung, Taiwan, R.O.C. \\ Yi-Lo Shen \\ Penghu Marine Biology Research Center, Fisheries Research Institute, Council of Agriculture, Penghu, Taiwan, R.O.C. \\ Jinn-Shing Weng \\ Coastal and Offshore Resources Research Center, Fisheries Research Institute,Council of Agriculture, Kaohsiung, \\ Taiwan, ROC. \\ Bambang Semedi \\ Coastal resilience and climate change adaptation research Group, Dep. of Fisheries and Marine Sciene, University of \\ Brawijaya, Indonesian
}

See next page for additional authors

Follow this and additional works at: https://jmstt.ntou.edu.tw/journal

Part of the Fresh Water Studies Commons, Marine Biology Commons, Ocean Engineering Commons, Oceanography Commons, and the Other Oceanography and Atmospheric Sciences and Meteorology Commons

\section{Recommended Citation}

Lee, Ming-An; Huang, Wei-Po; Shen, Yi-Lo; Weng, Jinn-Shing; Semedi, Bambang; Wang, Yi-Chen; and Chan, Jui-Wen (2021) "Long-Term Observations of Interannual and Decadal Variation of Sea Surface Temperature in the Taiwan Strait," Journal of Marine Science and Technology. Vol. 29: Iss. 4, Article 7.

DOI: $10.51400 / 2709-6998.1587$

Available at: https://jmstt.ntou.edu.tw/journal/vol29/iss4/7

This Research Article is brought to you for free and open access by Journal of Marine Science and Technology. It has been accepted for inclusion in Journal of Marine Science and Technology by an authorized editor of Journal of Marine Science and Technology. 
Long-Term Observations of Interannual and Decadal Variation of Sea Surface Temperature in the Taiwan Strait

Authors

Ming-An Lee, Wei-Po Huang, Yi-Lo Shen, Jinn-Shing Weng, Bambang Semedi, Yi-Chen Wang, and Jui-Wen Chan 


\title{
Long-Term Observations of Interannual and Decadal Variation of Sea Surface Temperature in the Taiwan Strait
}

\author{
Ming-An Lee ${ }^{a, b}$, Wei-Po Huang ${ }^{a}$, Yi-Lo Shen ${ }^{c}$, Jinn-Shing Weng ${ }^{d}$, Bambang Semedi ${ }^{\text {, }}$ \\ Yi-Chen Wang ${ }^{b, *}$, Jui-Wen Chan ${ }^{\mathrm{f}}$ \\ ${ }^{a}$ Center of Excellence for Ocean Engineering, National Taiwan Ocean University, Keelung, Taiwan, ROC \\ ${ }^{\mathrm{b}}$ EBFS, National Taiwan Ocean University, Keelung, Taiwan, ROC \\ ${ }^{c}$ Penghu Marine Biology Research Center, Fisheries Research Institute, Council of Agriculture, Penghu, Taiwan, ROC \\ ${ }^{d}$ Coastal and Offshore Resources Research Center, Fisheries Research Institute, Council of Agriculture, Kaohsiung, Taiwan, ROC \\ ${ }^{\mathrm{e}}$ Coastal Resilience and Climate Change Adaptation Research Group, Dept. of Fisheries and Marine Science, University of Brawijaya, \\ Indonesia \\ ${ }^{\mathrm{f}}$ Taiwan Ocean Research Institute, Kaohsiung City, Taiwan, ROC
}

\begin{abstract}
Long-term observations of interannual and decadal variation of sea surface temperature (SST) in the Taiwan Strait (TS) were studied for the period 1870-2018; the climatology data were obtained from the Met Office Hadley Centre, UK. In the study period, the highest annual mean and lowest SST observed were $25.3{ }^{\circ} \mathrm{C}$ in 1998 and $22.4{ }^{\circ} \mathrm{C}$ in 1919 , respectively. Six distinct regimes were identified. The first regime of fairly stable or slightly cooling SST lasted through the 1920s. The two regime shifts of 1919-1945 and 1976-1977 to 1998 led to the two fast warming trends of $2.0{ }^{\circ} \mathrm{C}$ in 26 years, from $22.5{ }^{\circ} \mathrm{C}$ in 1919 up to $24.5{ }^{\circ} \mathrm{C}$ in 1945 , and of $2.4{ }^{\circ} \mathrm{C}$ in 22 years, from $22.9{ }^{\circ} \mathrm{C}$ in 1977 up to $25.3{ }^{\circ} \mathrm{C}$ in 1998 , respectively. Another two regime shifts initiated in 1945 (1945-1976) and 1998-1999 (1998-2011) that led to $1.6{ }^{\circ} \mathrm{C}$ and $1.0{ }^{\circ} \mathrm{C}$ cooling, respectively. A recent and fast warming trend with $0.63{ }^{\circ} \mathrm{C} /$ decade suggested that the warming hiatus from 1998 to 2011 faded away since 2012. The spatial distribution of climate trends through the decades across the TS revealed a strong spatial gradient along the Strait. In the north (southern East China Sea), the magnitude and rate of the overall SST warming between 1870 and 2018 were approximately 1.5 times than those in the south (northern South China Sea).
\end{abstract}

Keywords: Taiwan strait, Sea surface temperature, Decadal variation, Warming hiatus

\section{Introduction}

$\mathrm{T}$ he Taiwan Strait (TS) is one of the world's most important passages connecting two large marine ecosystems (LMEs), namely the East China Sea (ECS) and South China Sea (SCS). A total of 504 and 288 million tons of fish were fished from the SCS and ECS LMEs, respectively, between 1950 and 2014; however, climate change is one of the major anthropogenic stressors impacting these two LMEs currently [1]. For example, under a high emissions scenario (representative concentration pathway 8.5) with status quo fishing in 2100 , a $99 \%$ decline in biomass of 17 functional groups (e.g., benthic crustaceans, juvenile large croakers, and pomfret) in the SCS and eight functional groups (e.g., small demersal fishes, jellyfish, and large croakers) in the ECS were evaluated [1]. Interestingly, this strait is a favorable habitat zone for marine fishing grounds [2-9]. Investigations regarding distribution and 
habitat suitability zone of coastal commercial species were conducted in the coastal waters of the TS, considering stock restoration and conservation [10-12]. In addition to climate variability, the ECS LME experienced a fast warming rate between 1982 and 2006 compared with the adjacent SCS LME; when area-averaged annual mean sea surface temperature (SST) of the ECS LME rose by $1.22{ }^{\circ} \mathrm{C}$, the SST of the SCS LME rose by $0.44{ }^{\circ} \mathrm{C}$ [13]. Belkin and Lee [14] revealed the three epochs identified in the TS from 1957 to 2011. The first epoch of the SST cooling lasted through 1976. The regime shift from 1976 to 1977 led to an extremely rapid warming of $2.1^{\circ} \mathrm{C}$ in 22 years. Another regime shift occurred from 1998 to 1999 , resulting in a $1.0^{\circ} \mathrm{C}$ cooling by 2011. A similar trend was observed by another study using the $5^{\circ} \times 5^{\circ}$ Hadley Centre Sea Ice and SST (HadISST1) for the period of 1900-2006 [15]. The largest warming trend appears near to the estuary and the offshore region of the ECS with the annual mean warming rates more than $2.4{ }^{\circ} \mathrm{C}$ in 100 years.

Water in the TS mainly flows northward owing to the pressure gradient associated with large-scale circulation [16-18]. In wintertime, northeasterly monsoon winds drive the cold China Coastal Current (CCC) to flow southward along the west coast of the TS, whereas the warm Kuroshio Branch Current $(\mathrm{KBC})$ enters the TS through the Penghu Channel from the southeast [19]. However, the winter SST in the TS is influenced by the large-scale climate variability such as El Niño-Southern Oscillation (ENSO) [20,21]. It has been reported that the winter SST in the TS is colder with strong wind in the northwestern part and warmer in the southeastern region during a La Niña period (1998/1999, 2008 , 2011) $[3,22]$, whereas the influence was reversed during an El Niño period (1997/1998) [20]. Thus, continuous strong winds drove the cold current from southeast to southern Taiwan, and the warm currents of higher than $20^{\circ} \mathrm{C}$ retreated to the SCS, which resulted in a significant drop in water temperature [23]. Hsieh et al. [24] and Chang et al. [23] reported an extremely low water temperature event in February 2008 that resulted in the death of wild fish surrounding the coasts of the Penghu Archipelago (PHA) in the southern TS. The influence of the cold SST variation relating to La Niña also reflected through the catch per unit effort (CPUE) of pelagic species, such as hairtail, skipjack tuna, and rabbitfish [25]. Otherwise, the influence of the extreme cold water event on cage aquaculture resulted in an economic loss of approximately US $\$ 1$ million for fish farmers at the PHA in the 2008 winter [3]. The annual production of cage culture at the PHA was 4600 tons in 2007. However, production declined to 1200 tons after the cold water event in 2008 that led to the death of more than $70 \%$ of cultured cobia and groupers. A similar cold water event with the low SST (less than $18{ }^{\circ} \mathrm{C}$ ) occurred again in the 2011 winter [3]. More than $70 \%$ of the cobia (Rachycentron canadum), a major species of the cage culture, died at the end of the January 2011, and more than 500 tons of the caged fish were cleaned in 1 week by fish farmers. Although the strong winds $(>6 \mathrm{~m} / \mathrm{s})$ during the La Niña event in winter affect the cold SST intrusions into the TS, the relationship between cold water intrusions and wind speeds during the La Niña event is not precisely understood [3]. One of the most intriguing aspects of the climate variability in the TS is related to the strait fishery. Lan et al. [26] indicated that the CPUE of grey mullet had significantly high correspondence with the annual Pacific decadal oscillation (PDO) index. They also suggested that the PDO affects the migration of the grey mullet, but increases in SSTs have a more significant influence on the decreased catches of the grey mullet after 1980. The fishing grounds of the grey mullet might have shifted to the north following changes in the $20^{\circ} \mathrm{C}$ isotherm of the strait after 1998. Kuo et al. [27] analyzed the long-term advanced very high resolution radiometer SST change in the TS using the rotated empirical orthogonal function method for the period of January 1980 to February 2013. The relationship between the ENSO phase and the SST variation in the TS exhibited spatial and decadal variations. The SST in the northern TS tended to be warmer (cooler) during El Niño (La Niña) years compared with normal years. However, an opposite relationship was found in the southern TS- the SST cooling (warming) occurred during El Niño (La Niña) years and this phenomenon existed only after the SST warming regime shift (1992-1994).

The aforementioned assessments indicate that some consequences of the climate variability in the TS are detrimental to certain areas of the human activities, such as fisheries, aquaculture, and coastal development. Ho et al. [28] further recommended that the catch ratio of coastal species with dual peaks in both summer and fall varied greatly before 1978. Increasing trends began in the 1980s and accelerated until 1998. As a result of this increase, the previous concentration of the fishing season in the winter months became highly diffuse. However, the change coincides with trends in sea surface temperature fluctuations. In this study, we examined the interannual and decadal variability of the SST in the TS during the period of 1870-2018, considering the importance of the TS. 


\section{Data and methods}

The main dataset used in this study is the global climatology of the SST maintained by the Met Office Hadley Centre, UK. The Hadley climatology consists of the global fields with $1^{\circ} \times 1^{\circ}$ spatial resolution and monthly temporal resolution, from 1870 till date [29,30]. This dataset has been used in numerous climate-related studies and climate assessments that include the most recent reports of the International Panel on Climate Change (IPCC), IPCC-2007 [31] and IPCC-2013 [32]. Being the dataset of choice for global studies, the Hadley climatology has been recently explored to study regional variability of the global climate change [13], a subject largely ignored by the IPCC-2007 and IPCC2013.

Following the methodology of the Belkin and Lee [14]; we approximated the study area by a polygon defined on a $0.25^{\circ} \times 0.25^{\circ}$ grid between $22^{\circ} \mathrm{N}$ and $26^{\circ} \mathrm{N}$ and smoothly interpolated the HadISST1 onto this grid using the bilinear interpolation algorithm [33] based on the MATLAB software. The monthly SSTs were area-weight averaged to generate individual monthly SSTs; these individual monthly SSTs were averaged to produce annual mean SSTs for the entire TS and to estimate climate trend for this strait. The quality check of the HadISST1 data in the TS was validated using the field data of the Central Weather Bureau and satellite data [34] by Belkin and Lee [14]. To study regional variations in climatic trends across the TS, the SST time series were extracted from the original HadISST1 dataset for each $1^{\circ}$ node of a total of 17 nodes (Fig. 1). The occurrence of the global warming since the mid1970s has been noted [31]. Therefore, the monthly
SST anomaly was retrieved based on the monthly means from 1971 to 2000 [35]. Further, February, May, August, and November were designated as the representative months for winter, spring, summer, and autumn, respectively. The analysis annual SST changes (e.g. warming or cooling rate) in decadal scale were described in Belkin and Lee [14]. The seasonal SST changes were compared for the warming trends in three periods of 1870-1919, 1920-1969, and 1970-2018. Some attempts have been made to predict the 10 -year climate over regions using this approach, including assessments of the role of the internal decadal variability [36]. Linear trends were estimated from the time series of the annual and decadal SSTs for each $1^{\circ}$ node.

\section{Results}

\subsection{Climatological patterns}

Fig. 2 illustrates the monthly averaged climatological SST patterns in February, May, August, and November from 1870 to 2018. The climatological SST in the TS varied seasonally. The monthly mean SST increased from February to August and subsequently decreased again from August to February. The SST also decreased spatially from the southeast toward the northwest from $22.5{ }^{\circ} \mathrm{C}$ to $15.5{ }^{\circ} \mathrm{C}$ in February (wintertime) and from $28.6^{\circ} \mathrm{C}$ to $27.8^{\circ} \mathrm{C}$ in August (summertime). The SST gradient was low in summertime compared with that during the other seasons. In February, the SST in the northwestern TS was generally lower than $16{ }^{\circ} \mathrm{C}$, which was employed as an index for the winter thermal front boundary between the CCC and the KBC in the TS [3]. The SST gradient increased gradually from

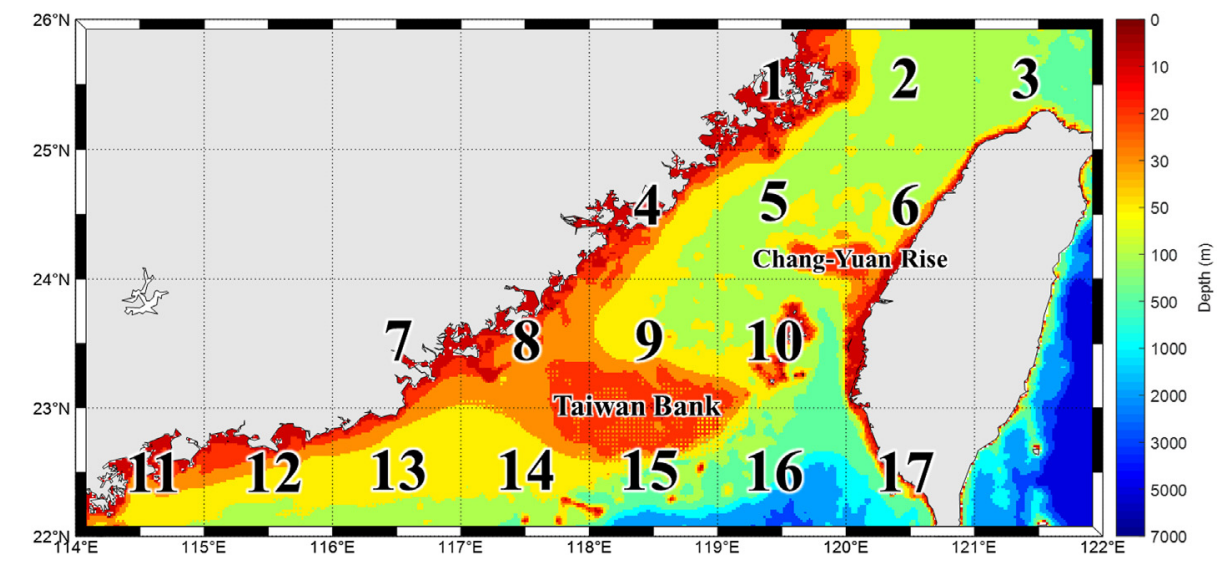

Fig. 1. Water depth (m) of the study area in the TS. The Hadley SST data are defined on a $1^{\circ}$ grid (black numbers). 


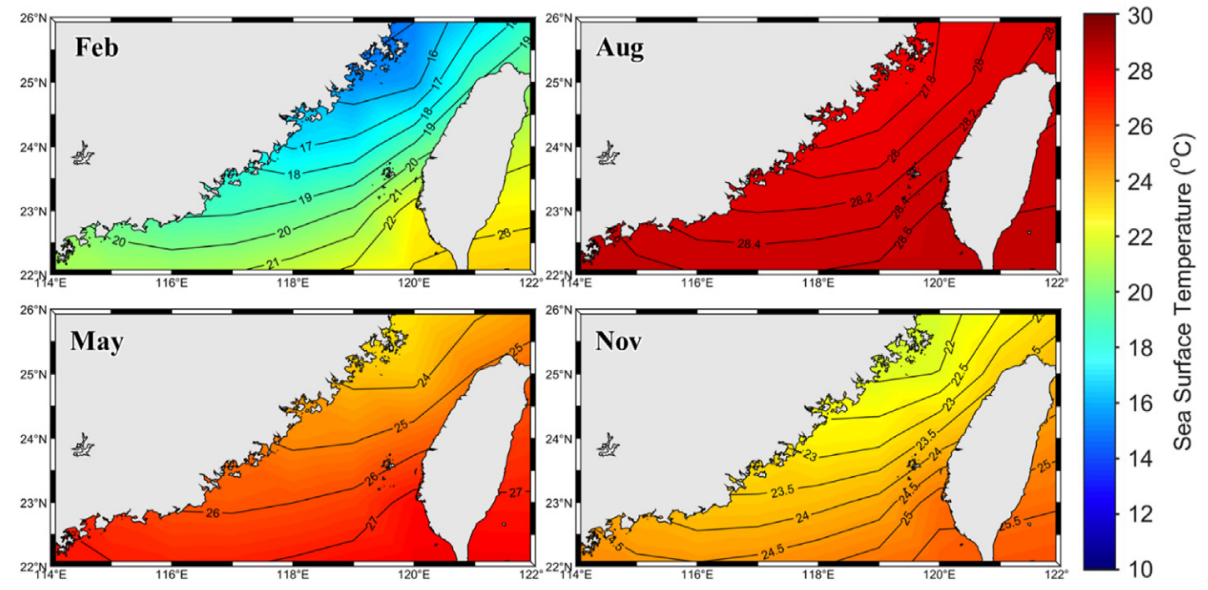

Fig. 2. The average climatological SST pattern in February, May, August, and November. The solid lines represent the isothermal lines.

November onward as the CCC intruded southward along the Chinese coast [37].

\subsection{Tempospatial variation of the SST}

The time series of the decadal SST for the entire TS is presented in Fig. 3. The decadal SST presented a cooling trend from 1870 to 1920 and a warming trend from 1920. The highest decadal mean SST was approximately $24.7^{\circ} \mathrm{C}$ in the period of 2000-2018, whereas the second highest decadal SST was approximately $23.7^{\circ} \mathrm{C}$ in the period of 1945-1965. After the year 1965, the decadal SST subsequently decreased from $23.7^{\circ} \mathrm{C}$ in $1950-1960$ to approximately $23.3{ }^{\circ} \mathrm{C}$ in $1970-1980$, which was approximately equal to the decadal SST in 1870-1880. The mean SSTs for the 50 -year decadal time scales of 1870-1919, 1920-1969, and 1970-2018 were $23.05{ }^{\circ} \mathrm{C}, 23.23{ }^{\circ} \mathrm{C}$, and $24.17{ }^{\circ} \mathrm{C}$, respectively.

Six distinct epochs from 1870 to present were found for the time series of the interannual SST (Fig. 4; Table 1). The interannual trend of the SST was similar to the decadal trend, but was more clear. The first epoch with a cooling rate of $0.15^{\circ} \mathrm{C} /$ decade was characterized by a gradual cooling from $23.8^{\circ} \mathrm{C}$ in 1870 to $22.4^{\circ} \mathrm{C}$ in 1918 (Table 1). After bottoming out in 1919 , the SST rose to $24.5^{\circ} \mathrm{C}$ in $1945-$ a $2.1^{\circ} \mathrm{C}$ increase in 26 years. During this period the SST warming rate was $0.4{ }^{\circ} \mathrm{C} /$ decade. After peaking in 1945 , the third epoch was characterized by a gradual cooling from $24.5^{\circ} \mathrm{C}$ in 1945 to $22.9{ }^{\circ} \mathrm{C}$ in 1976; the same cooling rate as that during the first epoch. After bottoming out in 1976 , the SST rose to $25.3^{\circ} \mathrm{C}$ in $1998-$ a $2.4{ }^{\circ} \mathrm{C}$ increase in 22 years. The SST warming rate was $0.61^{\circ} \mathrm{C} /$ decade from 1976 to 1998 , as the annual mean SST $\left(25.3^{\circ} \mathrm{C}\right)$ reached the peak of the study period in 1998. After peaking in 1998, the SST decreased to $24.2{ }^{\circ} \mathrm{C}$ in 2011 . The last epoch indicated that the SST significantly rose at a fast warming rate of $0.63{ }^{\circ} \mathrm{C} /$ decade from 2012 to present (Table 1).

In spatial variation, individual time series of the decadal SST analysis in grid nodes revealed significant details of the spatial variability across the

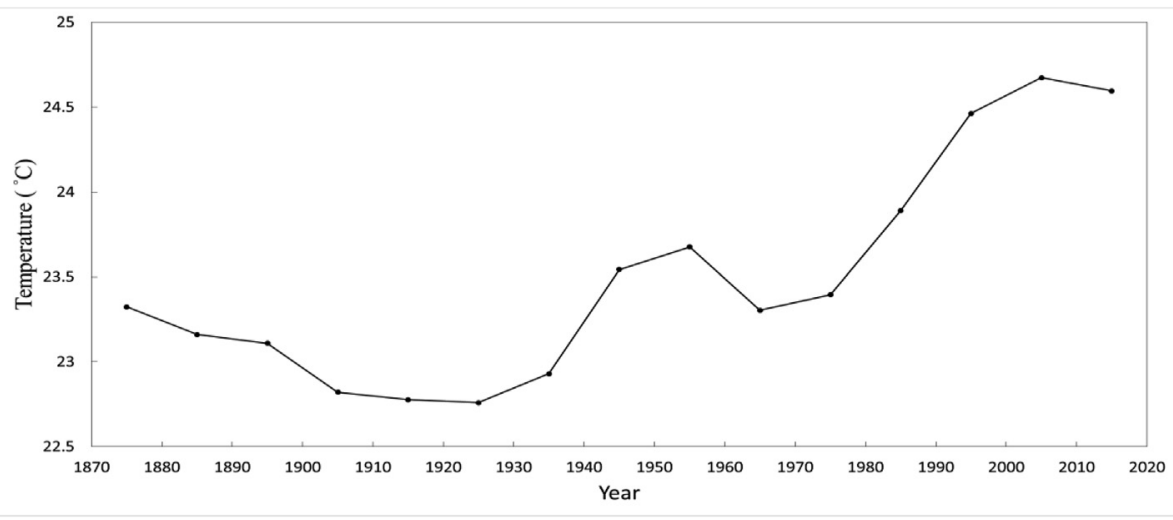

Fig. 3. Time series variability of the decadal SST in the TS. 


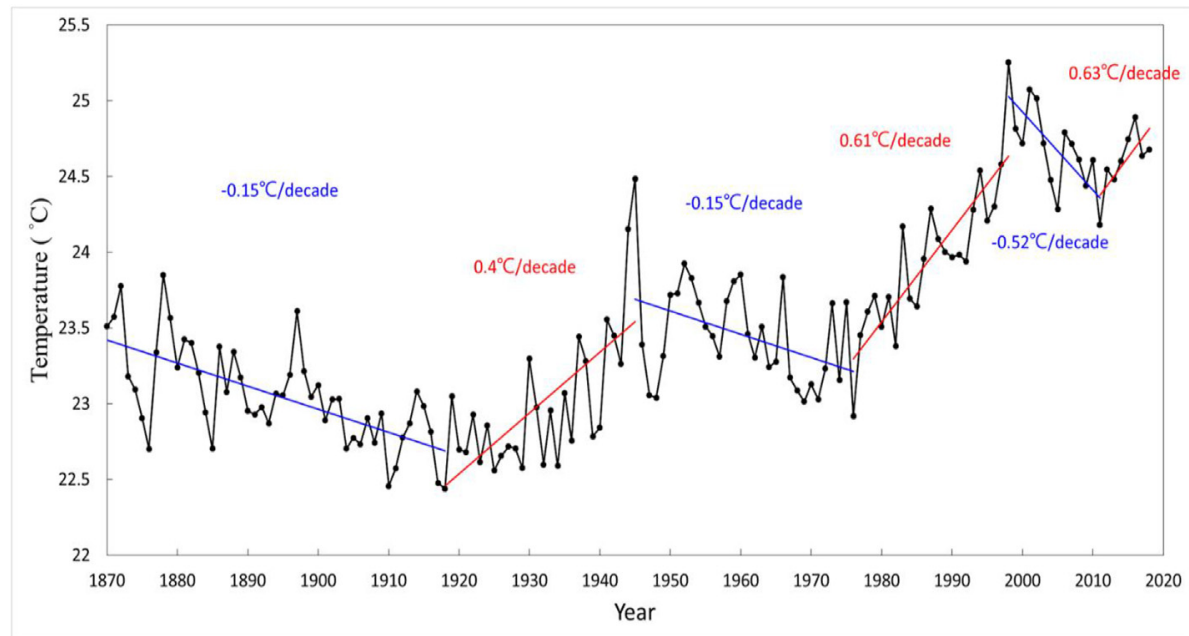

Fig. 4. Long-term annual variability of the SST in the TS (bounded by a polygon in Fig. 1).

Table 1. Comparison of maximum, minimum, and warming rates of the SST in the TS, ECS and YS since 1870.

\begin{tabular}{|c|c|c|c|c|c|c|c|}
\hline \multirow[t]{2}{*}{ Regions } & \multicolumn{3}{|l|}{$\mathrm{TS}^{\mathrm{a}}$} & \multirow[t]{2}{*}{ Periods } & \multirow{2}{*}{$\frac{\mathrm{YS}+\mathrm{ECS}^{\mathrm{b}}}{\text { Trends }}$} & \multirow[t]{2}{*}{ Periods ${ }^{\mathrm{d}}$} & \multirow{2}{*}{$\begin{array}{l}\frac{\mathrm{TS}+\mathrm{ECS}^{\mathrm{c}}}{\text { Warming rate }} \\
\left({ }^{\circ} \mathrm{C} / \text { decade }\right)\end{array}$} \\
\hline & $\begin{array}{l}\text { Maximum } \\
\left({ }^{\circ} \mathrm{C}\right)\end{array}$ & $\begin{array}{l}\text { Minimum } \\
\left({ }^{\circ} \mathrm{C}\right)\end{array}$ & $\begin{array}{l}\text { Warming rate } \\
\left({ }^{\circ} \mathrm{C} / \text { decade }\right)\end{array}$ & & & & \\
\hline \multicolumn{8}{|l|}{ Periods } \\
\hline $1870-1918$ & 23.8 & 22.4 & -0.15 & $1870-1940$ & cooling & Annual mean & +0.24 \\
\hline $1919-1945$ & 24.5 & 22.4 & +0.40 & $1940-1950$ & warming & February & +0.27 \\
\hline $1946-1976$ & 24.5 & 22.9 & -0.15 & 1950-1977 & cooling & August & +0.15 \\
\hline 1977-1998 & 25.3 & 22.9 & +0.61 & $1977-2016$ & warming & & \\
\hline 1999-2011 & 25.2 & 24.2 & -0.52 & & & & \\
\hline $2012-2018$ & 24.9 & 24.2 & +0.63 & & & & \\
\hline
\end{tabular}

${ }^{a}$ : this study; ${ }^{b}$ : source: Pei et al. [38]; ${ }^{\text {c: }}$ source: Liu and Zhang (2013) [15]; ${ }^{d}$ : years from 1900 to 2006.

strait. The stacked offset plot of the SST in 17 onedegree nodes (Fig. 5) demonstrated the synchronization of the SST changes. The decadal SST increased from $20.5{ }^{\circ} \mathrm{C}$ in the north node to approximately $27^{\circ} \mathrm{C}$ in the south node. For all of the nodes $1-17$, the time series of the decadal SST trends was similar, but two SST gaps were observed in the northwestern TS "node 1" and the middle TS

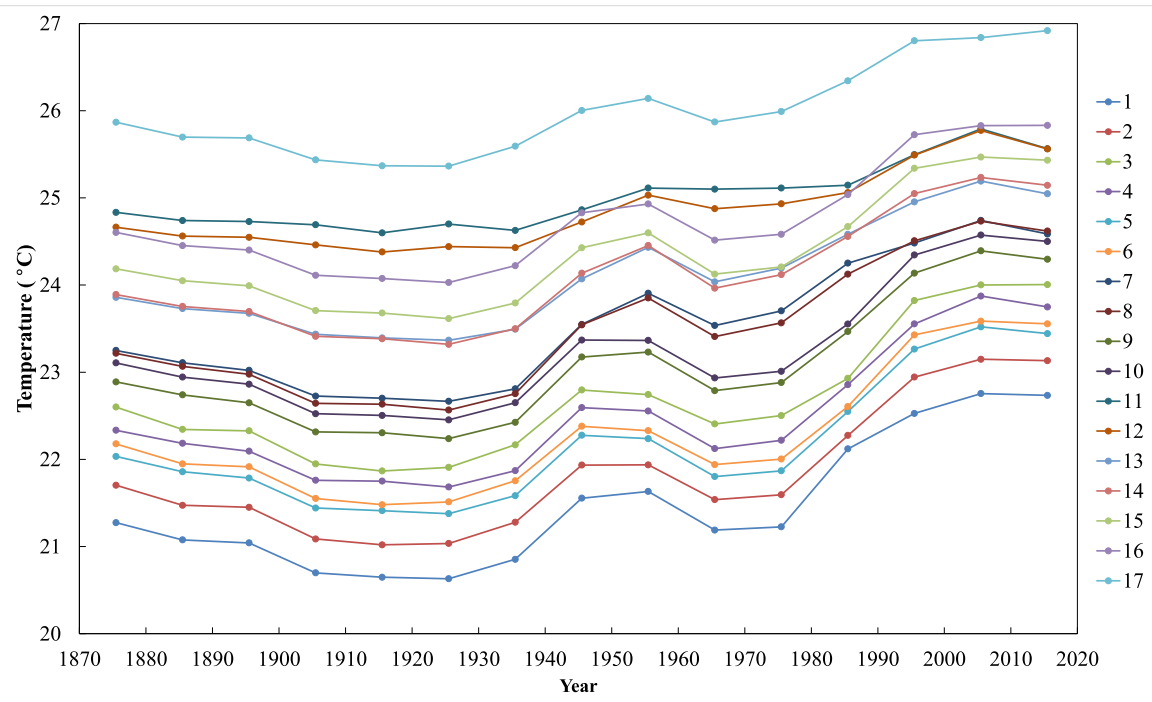

Fig. 5. Composite no-offset plot of the decadal SST time series in 17 one-degree nodes in the TS, 1870-2018. 
near the Taiwan Bank "nodes 9-10." At node 17 in the southeastern waters of the TS, the decadal SST was the highest (more than $25.3{ }^{\circ} \mathrm{C}$ ), whereas the SST was $1^{\circ} \mathrm{C}$ warmer than the neighboring node. At the nodes 8-10 in the waters of the south side Chang-Yuan Rise (CYR), the temperature difference was larger $\left(\sim 0.8{ }^{\circ} \mathrm{C}\right)$ during $1870-1930$ and subsequently reduced to approximately $0.5^{\circ} \mathrm{C}$ since 1970 . At the nodes 1-3 in the waters of the northern Taiwan, the decadal SST was the lowest (less than $22{ }^{\circ} \mathrm{C}$ ) during 1870-1920, but the decadal temperature significantly increased since the 1970s.

\subsection{Long-term changes and trends in the SST}

Fig. 6 depicts the interannual variability of the monthly SST anomaly based on the period of 1971-2000 in the TS. It is evident that the SST anomaly was significantly higher during 1990-2018, whereas it was relatively low during 1870-1940. Although the stacked offset plot of the SST time series in 17 nodes indicates the synchronous nature of temporal variability across the TS (Fig. 7), the SST anomaly from 1940 to 1990 varied seasonally (Fig. 6).

The mean SST change was slightly lower $\left(0.33^{\circ} \mathrm{C}\right)$ in the southern nodes (nodes 11-17) than that in the northern nodes (nodes 1-3), whereas the change in SSTs in the southern nodes in winter (December to February) and summer time (June to August) were lower $\left(\sim 0.03^{\circ} \mathrm{C}\right.$ and $0.46^{\circ} \mathrm{C}$, respectively), than those in the northern nodes. The highest and lowest SST changes were approximately $2.53{ }^{\circ} \mathrm{C}$ at node 7 in the February and $0.73{ }^{\circ} \mathrm{C}$ at node 11 in the August, respectively (Fig. 7).

The spatial SST change between 1870 and 2018 in different time scales in the TS are presented in
Fig. 8. Till now, the warming SST trends were examined, but the spatial SST changes at $1^{\circ}$ grid spatial resolution significantly varied in different time scales. The SST change in space decreased approximately from $-0.26{ }^{\circ} \mathrm{C}$ to $-0.91{ }^{\circ} \mathrm{C}$ during 1870-1919, whereas the SST change increased approximately from $0.39{ }^{\circ} \mathrm{C}$ to $1.36{ }^{\circ} \mathrm{C}$ and $0.8^{\circ} \mathrm{C}-2.15^{\circ} \mathrm{C}$ for the two periods of $1920-1969$ and 1970-2018, respectively.

Analyzing seasonal time series of the SST changes in three periods, namely 1870-2018, 1920-2018, and 1970-2018, revealed significant spatiotemporal details of the decadal variability across the strait (Figs. 9-11). The SST changes significantly varied by season. The SST changes in February during 1920-2018 and 1970-2018 were higher (approximately $1.0{ }^{\circ} \mathrm{C}$ ) than that during $1870-2018$, whereas the changes in August in the former two periods were lower than that in the latter. The SST change significantly increased (more than $2.4^{\circ} \mathrm{C}$ ) across the TS, especially in February during 1920-2018. This indicated that the decadal warming rates in recent (approximately 50 and 100) years (e.g., 1970-2018 and 1920-2018) were different and higher than that in approximately 150 years (e.g., 1870-2018). In addition, a two-fold increase in warming rates from the southwest $\left(0.8{ }^{\circ} \mathrm{C}-1.18{ }^{\circ} \mathrm{C}\right)$ to the northeast $\left(2.1^{\circ} \mathrm{C}-2.23{ }^{\circ} \mathrm{C}\right)$ during $1920-2018$ and $1970-2018$ was evident.

\section{Discussion and conclusion}

This study examined the interannual and decadal variability of the SST in the TS during 1870-2018. The composite no-offset plots of the interannual and the decadal SST time series in the TS (Figs. 4-5 and 9-11) present the obvious difference. They revealed

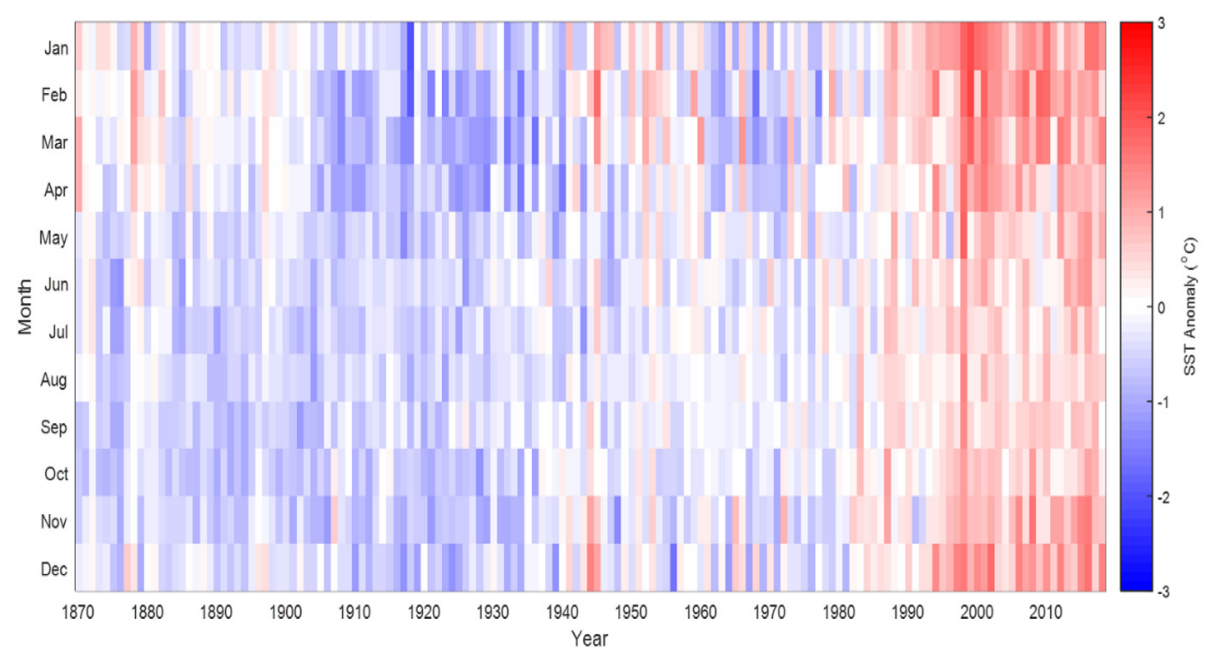

Fig. 6. Long-term variations in the SST anomalies in the TS for the period of 1870-2018. 


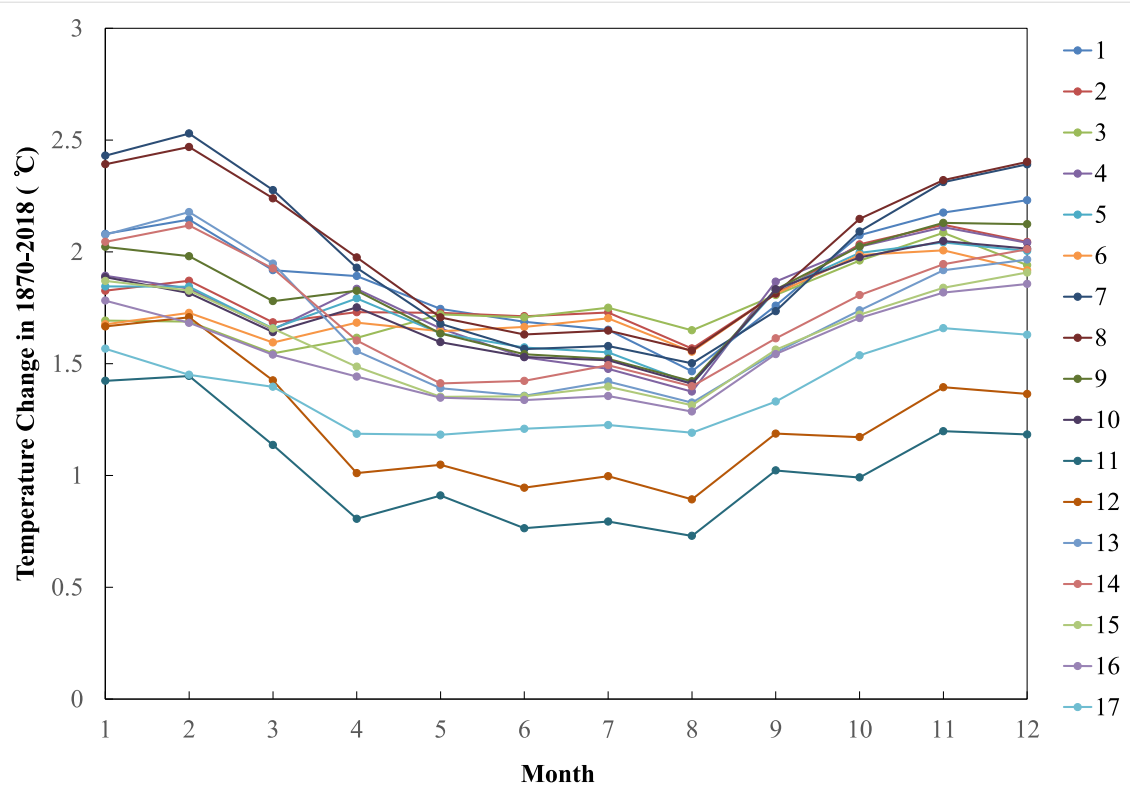

Fig. 7. Stacked offset plot of the SST time series in 17 nodes across the TS. The synchronous nature of the temporal variability is evident.

that the highest annual mean $\left(25.3^{\circ} \mathrm{C}\right)$ and the lowest SST $\left(22.4^{\circ} \mathrm{C}\right)$ were observed in 1998 and 1919, respectively. The SST change significantly decreased during 1870-1919, whereas the change subsequently increased during 1920-1969 and 1970-2018. These findings were similar to those of Pei et al. [38]; who described that the decadal SST trends were interactive between cooling and warming across the ECS and YS. They revealed that warming trends were observed during 1940-1950 and 1977-2016, whereas cooling trends were observed during 1870-1940 and 1950-1977 (Table 1).

Analyzing interannual SSTs revealed six epochs between 1870 and 2018. The first two epochs of fairly stable cooling rate $\left(0.15{ }^{\circ} \mathrm{C} /\right.$ decade $)$ were observed between 1870 and 1920 and of slightly warming rate $\left(0.40{ }^{\circ} \mathrm{C} /\right.$ decade) lasted through the 1950 s. Another study presented similar trends for the YS and ECS [38]; it revealed that SST cooling trends were observed during 1870-1940 and they slightly increased from 1940 to 1950 . After these warming trends in the 1940s, the third epoch with a fairly stable cooling rate $\left(0.15{ }^{\circ} \mathrm{C} /\right.$ decade $)$ was observed from 1946 to 1976. Belkin and Lee [14] reported similar trends, but further discussions on possible mechanisms of the cooling trends are still scant.

The fourth regime shift from 1976 to 1977 to 1998 led to a fast warming of $2.4{ }^{\circ} \mathrm{C}$ in 22 years; an increase from $22.9{ }^{\circ} \mathrm{C}$ in 1977 to $25.3{ }^{\circ} \mathrm{C}$ in 1998 . Yeh and Kim [39] inferred that this warming SST trend may be associated with global warming caused by enhanced ocean thermal advection associated with the Kuroshio [40]. Indeed, the warming rate of the TS was comparable with that of the ECS and much exceeds the warming rates of the Kuroshio and especially of the SCS [13]. However, Tseng et al. [41] did not observe any increasing trend in the simulated Kuroshio volume transport, presenting a doubt regarding the relationship between the SST and the intensification of the Kuroshio heat transport. Belkin [13] postulated another key role of the Yangtze River outflow associated with this warming trends of the TS. Park et al. [42] indicated that Yangtze River plays a positive role in the SST increase during summer because its temperature in the estuary has been increased by $2{ }^{\circ} \mathrm{C}$ since 1986 [43]. Belkin and Lee [14] speculated that the annual discharge of $800 \mathrm{Gt}$ of fresh water creates a buoyant plume that spreads across the entire southern ECS, occasionally reaching as far as the Japan Sea. In summer, the plume is warmer than the ambient offshore water. However, the role of the Yangtze River is still uncertain because its discharge has presented no increasing trend (e.g., [44]).

The last two epochs occurred between 1998 and 1999 and 2011, leading to a $1.0{ }^{\circ} \mathrm{C}$ decreasing from 1998 to 2011, and a $1.6{ }^{\circ} \mathrm{C}$ warming from 2012 to 2018. For the former, it is widely recognized that the global and regional (e.g., TS, ECS, YS) warming has slowed down drastically after the global temperature peaked in 1998 [14,45]. Liao et al. [46] found that this cooling trend coincided with the phase shift from decadal-to-multidecadal (DM) climate 

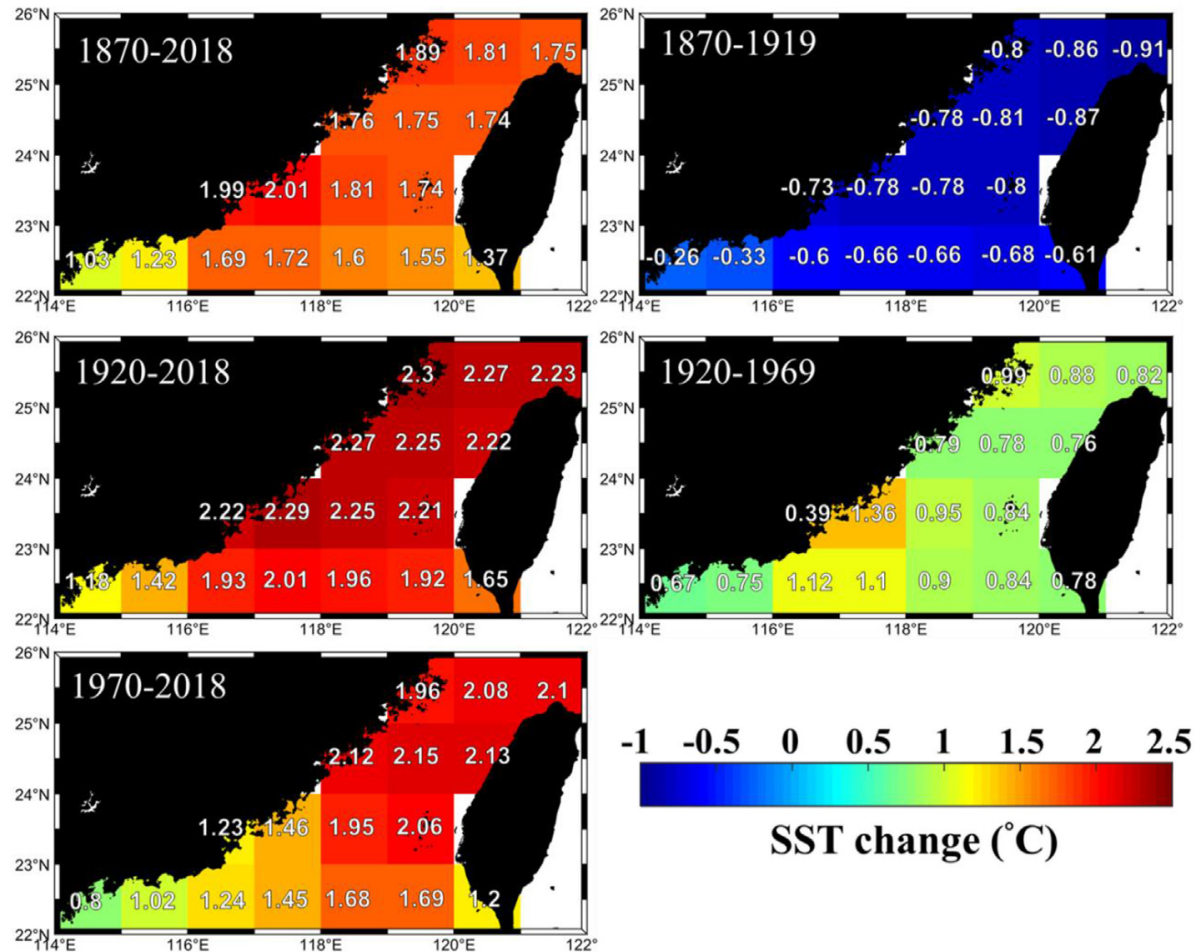

Fig. 8. The spatial SST change between 1870 and 2018 at different time scales in the TS.

variability (e.g., PDO and North Atlantic Oscillation [NAO]) in the coastal oceans of low and middle latitude. The coastal SST changes were larger than the changes of the global mean and open ocean, resulting in a fast increase in extreme hot or cold days, and thus, extreme hot or cold events [3,47]. This slowdown in the rate of the SST increase over a decade or more may be a pause in a DM variability process "warming hiatus" [46]. A global warming hiatus might imply a pause in the rate of heat energy increase in the Earth's system [48].
Interestingly, a fast warming trend with $0.63{ }^{\circ} \mathrm{C} /$ decade since 2012 was accompanying this "warming hiatus" after 1998. Kuo et al. [37] suggested that the East Asian winter monsoon (EAWM) may appear as one of the most important phenomena. They postulated that the SST warming and cooling phenomena were attributable to the weakening and strengthening of the EAWM before and after 2000, respectively. Ding et al. [49] revealed that the waning of the EAWM that occurred in the mid1980s ended in the early 2000s; the EAWM has been

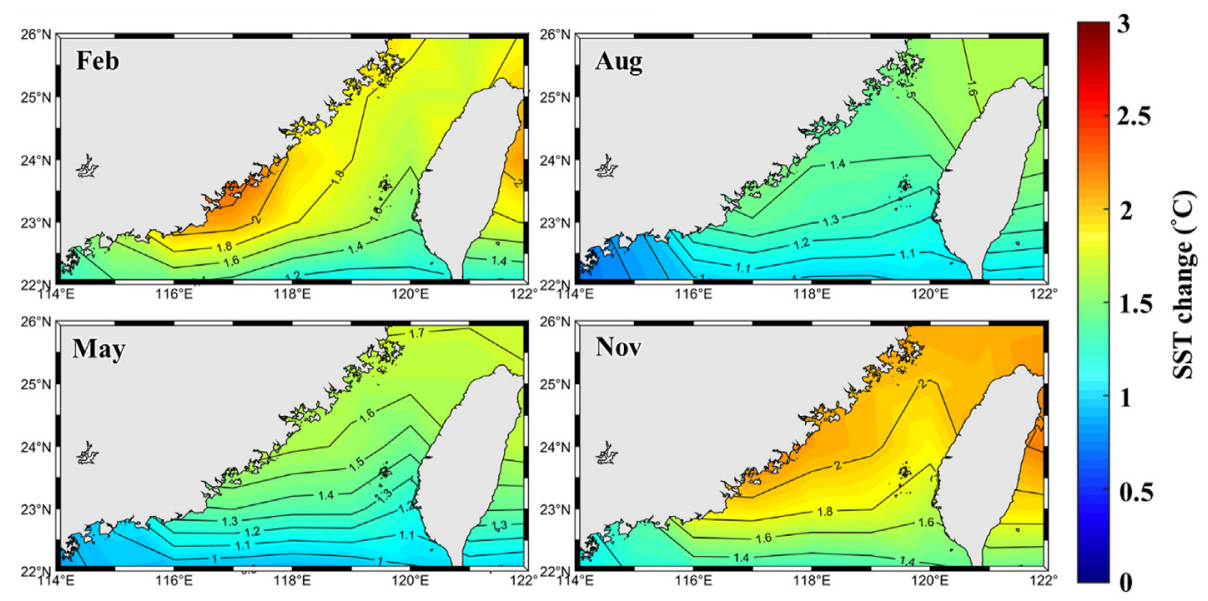

Fig. 9. Seasonal SST changes between 1870 and 2018 in the TS. 


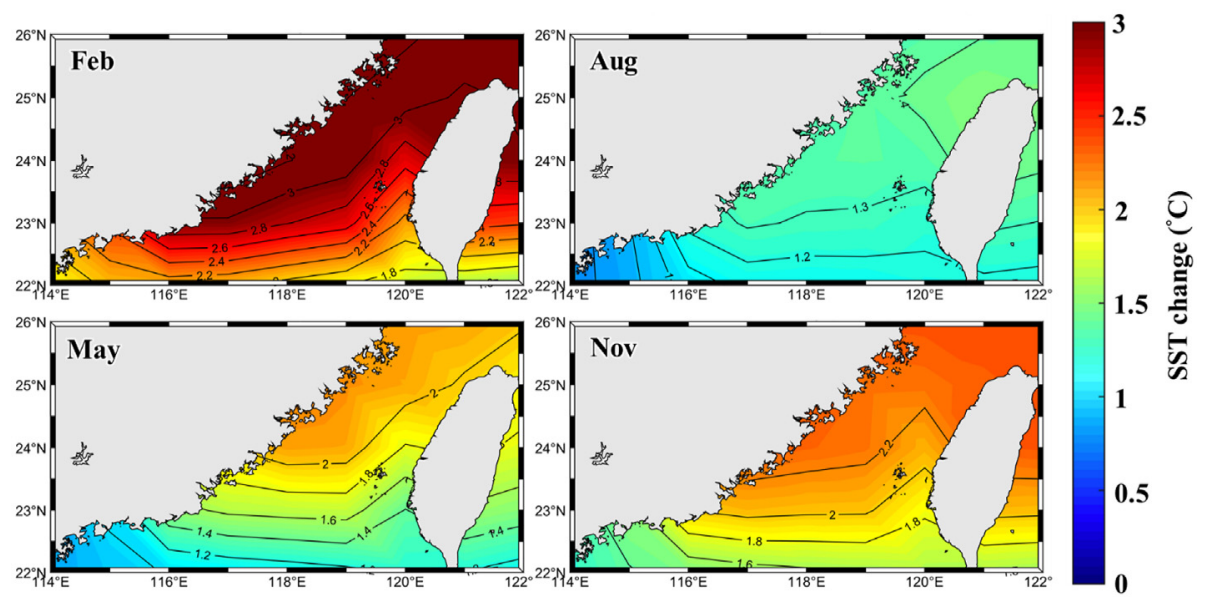

Fig. 10. Seasonal SST changes between 1920 and 2018 in the TS.

becoming stronger since the mid-2000s. This trend of EAWM variation has been examined using different winter monsoon indices [50,51]. The waning of the EAWM beginning in the mid-1980s was attributable to the shift in the dominant mode, the Arctic oscillation, considering atmospheric circulation [50], and this coincided with the most rapid warming of winter temperatures in East Asia, as well as was highly consistent with the global mean temperature trends [50,51]. Fig. 12 illustrates a plot of the winter (December to February) EAWM index, as defined by Liren et al. [52]. Larger (smaller) value indicates weaker (stronger) EAWM. From 1980 to 1998, the EAWM index demonstrated an increasing trend, peaking in 1998, indicating the weakening of the northeasterly monsoon. Subsequently, the EAWM index decreased over the following 13 years, exhibiting the strengthening trend of the northeasterly monsoon in the past decade [37]. After 2012, the EAWM index slightly increased again. This phenomenon coincided with a study by Liao et al. [46]; which suggested that the warming trend continued and strengthened after 1998. The DM variability, including Atlantic multidecadal oscillations, PDO, and NAO indices, can accelerate or decelerate global warming on the DM timescales [53]. Since 2013, the DM component has entered a warming phase; this is evident from the global, land, and ocean surface temperature time series. The larger contribution of the DM component and the long-term warming trend imply that warmer years may occur more frequently in the near future. Therefore, we revealed that the signal of so-called SST warming hiatus in the TS has faded away, and a warming trend is more remarkable and has even accelerated since 2012.

For long-term spatial variation in the TS, the mean SST changes in the southern nodes (nodes 11-17) were slightly lower $0.33{ }^{\circ} \mathrm{C}$ than those in the northern nodes (nodes 1-3), whereas the SST changes in the southern nodes in winter (December to next February) and summer (June to August) were lower approximately $0.03{ }^{\circ} \mathrm{C}$ and $0.46{ }^{\circ} \mathrm{C}$, respectively, than those in the northern nodes. The highest and lowest SST changes were approximately $2.53{ }^{\circ} \mathrm{C}$ at node 7 (west of the Taiwan Bank) in February and $0.73{ }^{\circ} \mathrm{C}$ at node 11 in August, respectively. These findings were similar to that of Kuo and Lee [21]; who discovered that this variation in the SST warming may relate to topography, where cold water bulge occupies the upper layer of the area north to the CYR in wintertime [18]. The most substantial warming region was around the winter fronts extending from the northwest of the CYR to the southern Taiwan Bank. Belkin and Lee [14] further reported this phenomenon: the northern Strait, which is colder than the southern Strait, warmed more than the southern Strait, resulting in a sharply reduced SST gradient along the Strait. They also induced an important practical ramification whether the possibility of a spillover across the shallow CYR in the upper layer $(10-20 \mathrm{~m})$ is because the Kuroshio/SCS waters move north along the east side of the TS. The Kuroshio impact is limited by the southeastern part of the TS, Penghu Channel, and Penghu Islands area. Warm waters of the SCS contribute to the Kuroshio branch flowing north via the Penghu Channel [18]. Park and Choi [54] presented the long-term warming trend over the SCS in winter and summer. The warming rates in winter and summer between 1950 and 2008 were $0.16{ }^{\circ} \mathrm{C} /$ decade and $0.13{ }^{\circ} \mathrm{C} /$ decade, respectively. Although the overall warming was similar in both the seasons, the governing processes were different. In winter, reduced heat loss to the air partially contributed to the warming, but in summer, heat 


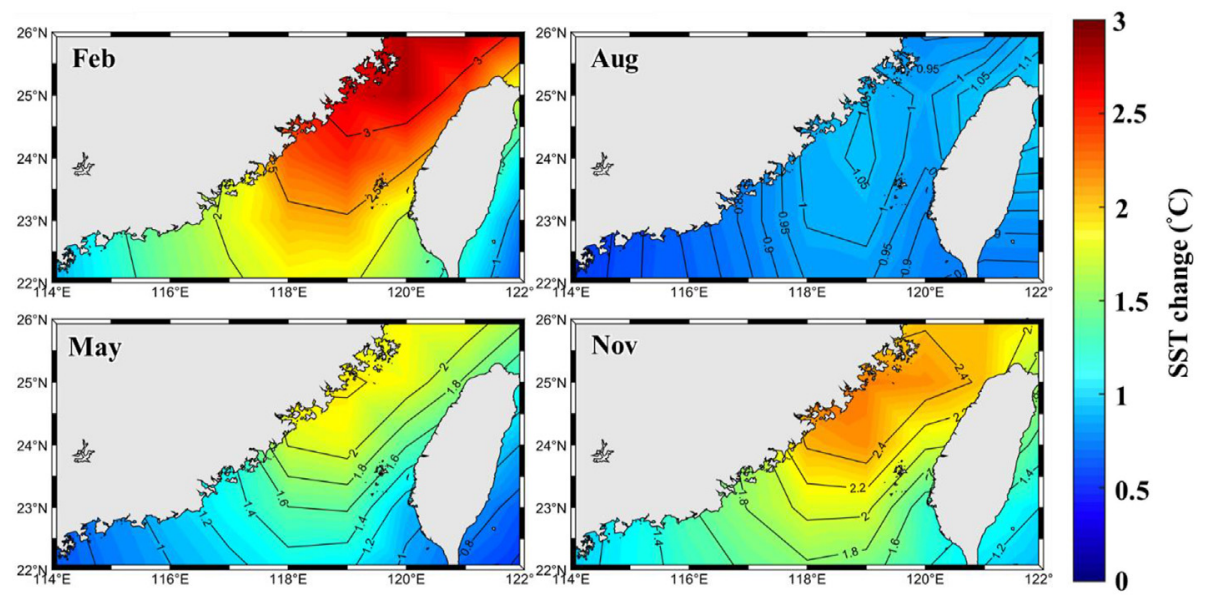

Fig. 11. Seasonal SST changes between 1970 and 2018 in the TS.

loss to the air was increased and thus the ocean warming was reduced. The partitioning of the northward warm water flow between the SCS/ Kuroshio waters and the TS waters is thus an open question. The establishment of a monitoring program to repeat in situ observations along with the CYR appears as a high-priority task. A cable observatory with multiple sensors distributed along the Rise is a viable alternative to the more expensive ship-based monitoring [14].

In summary, the multidecadal variability of the oceanic climate in the TS was studied using $1^{\circ} \times 1^{\circ}$ monthly climatology of the SST available from the Met Office Hadley Centre, UK, which is the most conveniently measured and frequently observed variable related to maritime climate. Six distinct regimes were identified between 1870 and 2018. The first regime of the fairly stable or slightly cooling SST lasted through 1930. The two regime shifts of 1930-1945 and 1976-1977 to 1998, respectively, led to two fast warming trends of $2.0{ }^{\circ} \mathrm{C}$ in 16 years, from $22.5{ }^{\circ} \mathrm{C}$ in 1930 up to $24.5^{\circ} \mathrm{C}$ in 1945 , and of $2.4^{\circ} \mathrm{C}$ in 22 years, from $22.9^{\circ} \mathrm{C}$ in 1977 up to $25.3^{\circ} \mathrm{C}$ in 1998. Another two regime shifts that initiated from 1945 (1946-1976) and 1998-1999 (1998-2011) leading to $1.6{ }^{\circ} \mathrm{C}$ and $1.0{ }^{\circ} \mathrm{C}$ cooling, respectively. The recent regime shift (since 2012) appears to have a warming trend. The spatial distribution of climatic trends in a decade across the Taiwan Strait revealed a strong spatial gradient along the Strait. In the north (the southern ECS), the magnitude and rate of the overall SST warming between 1870 and 2018 was approximately 1.5 times than those in the south (the northern SCS). Overall, HadISST1 may be a good data source for long-term observation on the trend and variation of SST in different time scale even if the spatial resolution $1^{\circ} \times 1^{\circ}$ is rough. Even though large amount of uncertainties with respect to the mechanisms for increasing the SST in the TS still exist. Various factors, including the topography,

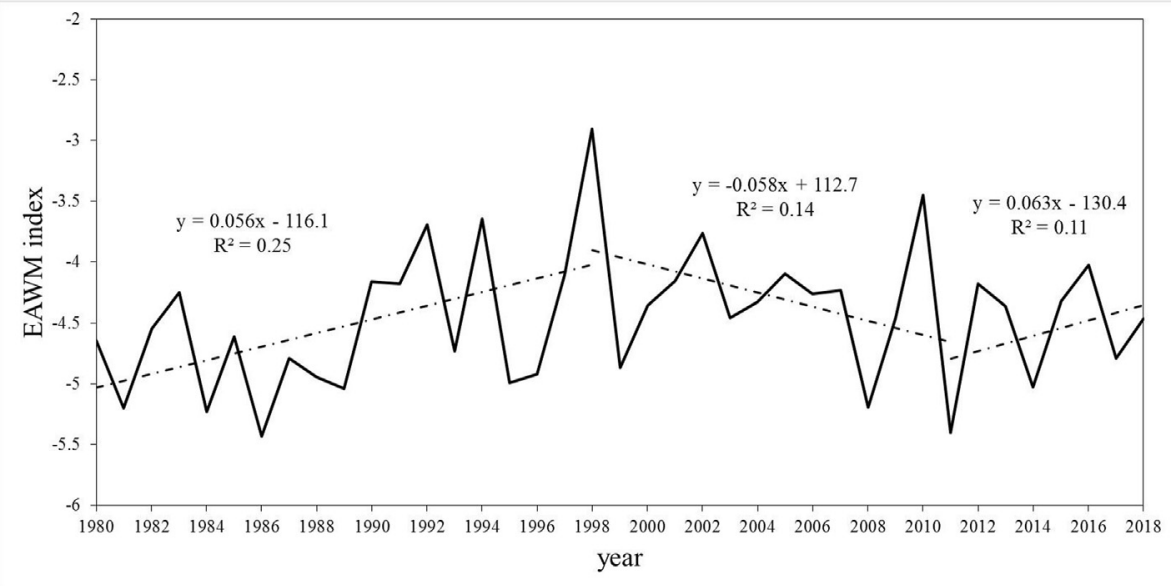

Fig. 12. The long-term annual variation of the winter (December to February) EAWM index during 1980-2018. 
surface net heat flux, surface wind, and geostrophic current velocity, affect the SST warming; however, their roles in high spatial resolution (e.g., 1-9 Km) are still difficult to quantify. In future, to discuss the possible factors that affect the interannual and the decadal SST variability in the TS, associated up-todate data products in high spatial resolution are required to be collected.

\section{Acknowledgements}

This study was a part of the Center of Excellence for Ocean Engineering of National Taiwan Ocean University study, sponsored by grants from the Ministry of Education of Taiwan. We gratefully acknowledge the long-term commitment of the Met Office Hadley Centre, UK, for assembling and maintaining a freely and easily accessible SST climatology. Mr. Chih Hsien Chang of the National Taiwan Ocean University kindly helped in SST data management of this article. This manuscript was edited by Wallace Academic Editing.

\section{References}

[1] Teh LSL, Cashion T, Alava Saltos JJ, Cheung WWL, Sumaila UR. Status, trends, and the future of fisheries in the east and South China seas. Fish Centre Res Rep 2019;27(1): 101pp.

[2] Chang CW, Tzeng WN. Species composition and seasonal occurrence of mullets (Pisces, Mugilidae) in the Tanshui estuary northwest Taiwan. J Fish Soc Taiwan 2000;27(4): 253-62.

[3] Chang Y, Lee MA, Lee KT, Shao KT. Adaptation of fisheries and mariculture management to extreme oceanic environmental changes and climate variability in Taiwan. Mar Pol 2013;38:476-82. 2013.

[4] Chiou WD, Lin GW. Reproductive biology of Codlet Bregmaceros lanceolatus in the coastal waters off southwestern Taiwan. J Fish Soc Taiwan 2013;40(3):153-69.

[5] Hsieh CH, Chen CS, Chiu TS, Lee KT, Shieh FJ, Pan JY, et al. Time series analyses reveal transient relationships between abundance of larval anchovy and environmental variables in the coastal waters southwest of Taiwan. Fish Oceanogr 2009; 18(2):102-17.

[6] Lee MA, Lee KT, Ou HC. The larval anchovy fishing groundformation in relation to osmotic pressure changes of the coastal waters along southern Taiwan. J Fish Soc Taiwan 1990;17(4):233-45.

[7] Lee MA, Chou SC, Lee KT, Lee PC. Distribution of fish larvae in relation to pycnocline in the coastal waters of TanShui, Taiwan. J Fish Soc Taiwan 1996;23(3):195-206. 1996.

[8] Lee CL, Chyn SS, Hwang ST, Kang WF. Demersal fish assemblages by bottom trawler in northwestern waters of Taiwan: a case study on cruise 21-20 July 2004. J Fish Soc Taiwan 2005;32(3):265-77.

[9] Wang YC, Chen WY, Chen YK, Kuo YC, Lee MA. Winter abundance and species composition of anchovy larvae associated with hydrological conditions in the coastal waters of Tanshui, Taiwan. J Mar Sci Technol 2018;26(3):465-74.

[10] Chen LC, Hsieh HJ, Tseng CT, Lin KJ, Lan KW. A preliminary investigation on catch composition and hotspots of hatchery release species for artisanal fishery in the coastal waters off Penghu. J Fish Soc Taiwan 2017;44(3): 185-95.
[11] Lo KC, Teng SY, Wang YC, Lee MA, Lin JL, Lu TH, et al. Resource structure of an artisanal gillnet fishery in the coastal waters of Tamsui, Taiwan. J Fish Soc Taiwan 2017; 44(3):147-57.

[12] Yu SF, Huang JZ, Lai CC, Wu LJ. Examining the xiao liuqiu offshore fishery resource structure and the distribution of released species. J Fish Soc Taiwan 2017;44(3):173-84.

[13] Belkin IM. Rapid warming of large marine ecosystems. Prog Oceanogr 2009;81(1-4):207-13.

[14] Belkin IM, Lee MA. Long-term variability of sea surface temperature in Taiwan Strait. Climatic Change 2014;124: 821-34.

[15] Liu Q, Zhang Q. Analysis on long-term change of sea surface temperature in the China Seas. J Ocean Univ China 2013; 12(2):295-300.

[16] Chuang WS. Dynamics of subtidal flow in the Taiwan Strait. J Oceanogr Soc Jpn 1985;41(2):65-72.

[17] Chuang WS. A note on the driving mechanisms of current in the Taiwan Strait. J Oceanogr Soc Jpn 1986;42(5):355-61.

[18] Jan S, Wang J, Chern CS, Chao SY. Seasonal variation of the circulation in the Taiwan Strait. J Mar Syst 2002;35(3-4): 249-68.

[19] Jan S, Chen CS, Wang J. A numerical study on currents in the Taiwan Strait during winter. Terr Atmos Ocean Sci 1998; 9:615-32.

[20] Kuo NJ, Ho CR. ENSO effect on the sea surface wind and sea surface temperature in the Taiwan Strait. Geophys Res Lett 2004;31(13):L13309.

[21] Kuo YC, Lee MA. Decadal variation of wintertime sea surface temperature in the Taiwan Strait. J Mar Sci Technol 2013;21(S):117-23.

[22] Cheng YH, Chang MH. Exceptionally cold water days in the southern Taiwan Strait: their predictability and relation to La Niña. Nat Hazards Earth Syst Sci 2018;18:1999-2010.

[23] Chang Y, Lee KT, Lee MA, Lan KW. Satellite observation on the exceptional intrusion of cold water in the Taiwan Strait. Terr Atmos Ocean Sci 2009;20(4):661-9.

[24] Hsieh HJ, Hsien YL, Tsai WS. Tropical fishes killed by the cold. Coral Reefs 2008;27(3):599.

[25] Lee MA, Yang YC, Shen YL, Chang Y, Tsai WS, Lan KW, et al. Effects of an unusual cold-water intrusion in 2008 on the catch of coastal fishing methods around Penghu Islands, Taiwan. Terr Atmos Ocean Sci 2014;25(1):107-20. 2014.

[26] Lan KW, Lee MA, Zhang CIk, Wang PY, Wu LJ, Lee KT. Effects of climate variability and climate change on the fishing conditions for grey mullet (Mugil cephalus L.) in the Taiwan Strait. Climatic Change 2014;126:189-202.

[27] Kuo YC, Lee MA, Chuang CC, Ma YP. Long-term AVHRR SST change analysis in the Taiwan Strait using the rotated EOF method. Terrestrial. Atmos Ocean Sci 2017;28(1):1-10.

[28] Ho CH, Lu HJ, He JS, Lan KW, Che JL. Changes in patterns of seasonality shown by migratory fish under global warming: evidence from catch data of Taiwan's coastal fisheries. Sustainability 2016;8:273.

[29] Rayner NA, Parker DE, Horton EB, Folland CK, Alexander LV, Rowell DP, et al. Global analyses of sea surface temperature, sea ice, and night marine air temperature since the late nineteenth century. J Geophys Res 2003; 108(D14):4407.

[30] Rayner NA, Brohan P, Parker DE, Folland CK, Kennedy JJ, Vanicek M, et al. Improved analyses of changes and uncertainties in sea surface temperature measured in situ since the mid-nineteenth century: the HadSST2 dataset. J Clim 2006;19(3):446-69.

[31] Trenberth KE, Jones PD, Ambenje P, Bojariu R, Easterling D, Tank AK, et al. Observations: surface and atmospheric climate change. In: Solomon S, Qin D, Manning M, Chen Z, Marquis M, Averyt KB, et al., editors. Climate change 2007: the physical science basis. Contribution of working group I to the fourth assessment report of the intergovernmental Panel on climate change. Cambridge, United Kingdom, New York, NY, USA: Cambridge University Press; 2007. p. 235-336. 
[32] Kirtman B, Power SB, Adedoyin JA, Boer GJ, Bojariu R, Camilloni I, et al. Near-term climate change: projections and predictability. In: Stocker TF, Qin D, Plattner G-K, Tignor M, Allen SK, Boschung J, et al., editors. Climate change 2013: the physical science basis. Contribution of working group I to the fifth assessment report of the intergovernmental Panel on climate change. Cambridge, United Kingdom and New York, NY, USA: Cambridge University Press; 2013.

[33] Prajapati A, Naik S, Mehta S. Evaluation of different image interpolation algorithms. Int J Comput Appl 2012;58(12):6-12.

[34] Lee MA, Tzeng MT, Hosoda K, Sakaida F, Kawamura H, Chang Y. Validation of JAXA/MODIS sea surface temperature aboard Terra and aqua in water around Taiwan. Terr Atmos Ocean Sci 2010;21(4):727-35.

[35] Meehl GA, Covey C, Delworth T, Latif M, McAvaney B, Mitchell JFB, et al. The WCRP CMIP3 multimodel dataset: a new era in climate change re-search. Bull Am Meteorol Soc 2007;88:1383-94.

[36] Hoerling M, Hurrell J, Kumar A, Terray L, Eischeid J, Pegion $\mathrm{P}$, et al. On North American decadal climate for 2011-20. J Clim 2011;24(16):4519-28.

[37] Kuo YC, Chan JW, Wang YC, Shen YL, Chang Y, Lee MA. Long-term observation on sea surface temperature variability in the Taiwan Strait during the northeast monsoon season. Int J Rem Sens 2018;39(13):4330-42.

[38] Pei YH, Liu XH, He HL. Interpreting the sea surface temperature warming trend in the Yellow Sea and East China Sea. Sci China Earth Sci 2017;60:1558-68.

[39] Yeh SW, Kim CH. Recent warming in the Yellow/East China Sea during winter and the associated atmospheric circulation. Continent Shelf Res 2010;30:1428-34.

[40] Zhang LP, Wu LX, Lin XP, Wu DX. Modes and mechanisms of sea surface temperature low-frequency variations over the coastal China seas. J Geophys Res: Oceans 2010;115:C08031.

[41] Tseng YH, Lin H, Chen HC. North and equatorial Pacific ocean circulation in the CORE-II hindcast simulations. Ocean Model 2016;104:143-70.

[42] Park T, Jang CJ, Jungclaus JH, Haak H, Park W, Oh IS. Effects of the Changjiang river discharge on sea surface warming in the Yellow and East China Seas in summer. Continent Shelf Res 2011;31:15-22.

[43] Zhou XY, Hu DB, Wang CZ, Hu XJ, Yao SK. Seasonal and interannual SST variations in the changjiang estuary. Perio Ocean Univ China 2005;35(3):357-62.

[44] Rong Y, Liu X. The decrease of the flow and its cause at Datong hydrological station of the Yangtze River. J Water Resour Res 2014;3:326-36 [in Chinese with English Abstract].

[45] Kim YS, Chan JJ, Yeh SW. Recent surface cooling in the Yellow and East China Seas and the associated North Pacific climate regime shift. Continent Shelf Res 2018;156: 43-54.

[46] Liao E, Lu W, Yan XH, Jiang Y, Kidwell A. The coastal ocean response to the global warming acceleration and hiatus. Sci Rep 2015;5:16630.

[47] Liao E, Jiang Y, Li L, Hong H, Yan X. The cause of the 2008 cold disaster in the Taiwan Strait. Ocean Model 2013;62 $1-10$.

[48] Yan XH, Boyer T, Trenberth K, Karl TR, Xie SP, Nieves V, et al. The global warming hiatus: slowdown or redistribution? Earth's Future 2016;4:472-82.

[49] Ding Y, Liu Y, Liang S, Ma X, Zhang Y, Dong S, et al. Interdecadal variability of the east asian winter monsoon and its possible links to global climate change. J Meteorol Res 2014;28:693-713.

[50] He SP, Wang HJ. An integrated East Asian winter monsoon index and its interannual variability. Chin J Atmos Sci 2012; 36:523-38. 2012 (in Chinese).

[51] Wang HJ, Fan K. Recent changes in the east asian monsoon. Chin J Atmos Sci 2013;37:313-8.

[52] Liren J, Sun S, Arpe K, Bengtsson L. Model study on the interannual variability of Asian winter monsoon and its influence. Adv Atmos Sci 1997;14(1):1-22.

[53] Zhang C, Li S, Luo F, Huang Z. The global warming hiatus has faded away: an analysis of 2014-2016 global surface air temperatures. Int J Climatol 2019;39:4853-68. 2019.

[54] Park YG, Choi A. Long-term changes of South China Sea surface temperatures in winter and summer. Continent Shelf Res 2017;143:185-93. 